\title{
Strategi Pemasaran Produk Pembiayaan \\ PT. BNI Syariah KC. Parepare
}

\author{
Juneda \\ Pasca Sarjana Institut Agama Islam Negeri (IAIN) Parepare \\ junedanurdin@gmail.com
}

\begin{abstract}
Abstrak
Bank BNI Syariah merupakan salah satu perbankan syariah di kota Parepare yang memiliki produk pembiayaan. Artikel ini membahas mengenai strategi pemasaran produk pembiayaan tersebut dengan menganalisis perspektif manajemen syariah. Hasil analisis menunjukkan bahwa strategi pemasaran produk pembiayaan bank BNI Syariah meliputi unsur bauran pemasaran $7 P$ yaitu produk, harga, tempat, promosi, orang/karyawan, fasilitas fisik, dan proses. Namun dari ketujuh unsur tersebut, strategi pemasaran yang paling efektif yang telah dilakukan adalah promosi dengan cara door to door yang bersifat kunjungan kepada nasabah. Strategi pemasaran tersebut sudah sesuai dengan prinsip manajemen Syariah.
\end{abstract}

Kata Kunci : Pemasaran, Manajemen Syaria,h Bank Syariah

\section{Pendahuluan}

Berdasarkan data statistik perbankan syariah per Januari 2018 yang dikeluarkan oleh Otoritas Jasa Keuangan (OJK), pada awal tahun 2018 total aset perbankan syariah sebesar Rp 414.185 miliar. ${ }^{1}$ Jumlah dan jaringan kantor perbankan syariah juga mengalami perkembangan, dimana pada tahun 1992-1998 hanya ada 1 unit bank syariah, maka pada tahun 2018, jumlah bank syariah di Indonesia telah bertambah menjadi 34 unit, yang terdiri dari 13 bank umum syariah dan 21 unit usaha syariah. Dengan jumlah kantor Bank Umum Syariah sebanyak 1.824 kantor dan kantor Usaha Unit Syariah sebanyak 346 kantor yang tersebar di seluruh Indonesia. Termasuk di Kota Parepare, Sulawesi Selatan terdapat 4 kantor Bank Syariah.

\footnotetext{
${ }^{1}$ Otoritas Jasa Keuangan (OJK), Statistik Perbankan Syariah - Januari 2018, diakses dari https://www.ojk.go.id/id/kanal/syariah/data-dan-statistik/statistik-perbankansyariah/Pages/Statistik-Perbankan-Syariah-Januari-2018.aspx, 5 Mei 2019.
} 
Kinerja dan kontribusi perbankan syariah terhadap perkembangan industri perbankan di Indonesia semakin meningkat. Kinerja ini semakin nyata ketika badai krisis ekonomi melanda Indonesia pada pertengahan Juli 1997. Ketika perbankan konvensional banyak yang terpuruk, perbankan syariah relatif dapat bertahan bahkan menunjukkan perkembangan. Hal ini terjadi karena beberapa hal, antara lain²: (1) beroperasi atas dasar prinsip syari'ah melalui bagi hasil, tidak beroperasi atas dasar bunga/riba, (2) tidak mengalami negative spread, (3) bertumpu terhadap usaha mikro, kecil dan menengah (UMKM) yang terbukti tangguh dan tahan dalam menghadapi krisis perekonomian nasional. Meskipun UMKM menjanjikan bagi masa depan ekonomi nasional, namun dalam perkembangannya seringkali dihadapkan dengan persoalan pendanaan. Sehingga kehadiran lembaga keuangan syariah merupakan momentum strategis bagi upaya pembebasan masyarakat pengusaha kecil dari kesulitan pendanaan dalam mengembangkan usaha ekonomi mereka.

Bank syariah dituntut untuk lebih giat mengembangkan usahanya, baik dalam sosialisasi, inovasi instrumen, dan produk bank. Pemberian pelayanan yang memuaskan dan memfungsikan bank syariah bukan hanya sekadar sebagai lembaga finansial dan komersial tapi juga lembaga keuangan sosial karena dengan masuknya bank syariah dalam kegiatan sosial akan melahirkan sentimen positif dalam berbagai hal. Hal ini tentunya akan sangat bermanfaat, sebagai langkah awal untuk dapat memformulasi sebuah paket strategi yang komprehensif, baik untuk pengembangan perbankan syariah secara umum maupun bagi masing-masing bank syariah. ${ }^{3}$

Kehadiran lembaga-lembaga perbankan dan keuangan tersebut hendaknya diimbangi dengan tumbuhnya para entrepreneur syariah.

\footnotetext{
2Muhammad, Bank Syariah: Problem dan Prospek Perkembangan di Indonesia, (Yogyakarta: Penerbit Graha Ilmu, 2005), h. 82-83.

${ }^{3}$ Muhammad Kamal Zubair, "Akselerasi Pertumbuhan Bank Syariah Di Indonesia”, Jurnal Fakultas Hukum UII, 2008, (online), h. 1. Dalam https://www.neliti.com/ publications/89402/akselerasi-pertumbuhan-bank-syariah-di-indonesia (diakses pada tanggal 11 Oktober 2019).
} 
Tumbuhnya etos entrepreneurship yang tinggi, khususnya bagi generasi umat akan berdampak positif terhadap kemajuan dan kebangkitan ekonomi umat sebagaimana yang terjadi di masa silam sekaligus berdampak positif bagi lembaga perbankan dan keuangan itu sendiri. Fenomena perkembangan perbankan syariah dapat memberikan akses yang lebih luas kepada masyarakat, khususnya pengusaha muslim. Dengan adanya bank syariah, mereka bisa bertransaksi dengan bank tanpa khawatir adanya unsur riba.

Pertumbuhan enterpreneur di Kota Parepare dapat dilihat dengan perkembangan Usaha Mikro, Kecil, dan Menengah (UMKM) bahkan Industri Kecil Menengah (UMKM). Berdasarkan data yang diperoleh dari Dinas Perdagangan dan Industri Kota Parepare jumlah unit usaha UMKM dari tahun 2016-2018 terus mengalami berkembangan tiap tahunnya, hingga pada akhir tahun 2018 tercatat sejumlah 10.839 unit usaha UMKM ${ }^{4}$ Dengan melihat besarnya jumlah unit usaha, dimana sebagian besar dari mereka adalah muslim, maka seharusnya semakin banyak pula yang menggunakan produkproduk perbankan syariah untuk pengembangan usahanya, seperti halnya produk pembiayaan.

Kenyataan di lapangan menggambarkan kurangnya minat para pengusaha UMKM dalam menggunakan produk-produk pembiayaan yang ditawarakan oleh beberapa perbankan syariah yang ada di kota Parepare. Hal ini ditandai dengan jumlah nasabah pembiayaan BNI Syariah yaitu pembiayaan 2 IB Hasanah dan pembiayaan 3 IB Hasanah hanya berjumlah 92 orang. ${ }^{5}$ Padahal, jika mereka menggunakan produk pembiayaan bank syariah, mereka bisa bertransaksi dengan bank tanpa khawatir adanya unsur riba.

Dengan melihat semakin ketatnya persaingan dalam dunia perbankan, maka bank syariah harus memiliki strategi yang tepat untuk memenangkan

\footnotetext{
4Dinas Perindagkop dan UKM, Dokumen Perubahan Renstra Dinas Perindagkop dan UKM 2013-2018 diakses dari https://pareparekota.go.id/wp-content/uploads/ 2017/09/Renstra-Perindag-2013-2018..pdf, 5 Mei 2019.

${ }^{5}$ Survei awal oleh peneliti pada Kantor PT. BNI Syariah Cabang Parepare.
} 
persaingan tersebut. Bank syariah harus secara terus menerus melakukan berbagai inovasi, termasuk mendisain berbagai produk, baik penghimpunan dana maupun pembiayaan semenarik mungkin.

Perbankan syariah dalam hal ini merupakan produsen yang mempunyai produk berupa barang dan jasa yang telah dirancang sesuai kriteria syariah untuk ditawarkan kepada masyarakat luas termasuk para pengusaha muslim. Posisi pengusaha muslim adalah sebagai konsumen bank syariah. Oleh karena itu, dalam rangka meningkatkan kinerja operasionalnya, maka bank syariah harus memperhatikan perilaku konsumennya yang mencerminkan mengapa seseorang memilih dan membeli produk/jasa baik yang menyimpan dana maupun yang melakukan pembiayaan sehingga dapat meningkatkan efektifitas kinerja bank.6

Secara umum setiap konsumen akan memperhatikan dan mempertimbangkan faktor-faktor tertentu untuk memutuskan mengambil pembiayaan. Untuk itu bank syariah harus dapat membaca peluang serta dapat mengidentifikasikan kebutuhan konsumen, termasuk dalam hal ini harus memperhatikan strategi pemasaran terkhusus dalam produk pembiayaan PT. BNI Syariah Kota Parepare.

\section{Strategi Pemasaran}

Strategi adalah ilmu siasat perang atau akal (tipu muslihat) untuk mencapai suatu maksud.7 Strategi merupakan serangkaian keputusan dan tindakan yang diarahkan untuk mencapai tujuan perusahaan. Pengertian lain mengatakan Strategi adalah serangkaian rancangan besar yang menggambarkan bagaimana sebuah perusahaan harus beroperasi untuk mencapai tujuannya, dan sekaligus dapat dibentuk strategi yang tertealisasi

\footnotetext{
${ }^{6}$ Hamid, A., \& Zubair, M. K. (2019). Implementasi Etika Islam Dalam Pemasaran Produk Bank Syariah. BALANCA: Jurnal Ekonomi dan Bisnis Islam, 1(1), 16-34.

${ }^{7}$ Makhalul Ilmi, Teori dan Praktek Mikro Keuangan Syariah, (Yogyakarta: UII Press, 2001), h. 2. Lihat, Semaun, S. (2019). Determinan Bauran Pemasaran Jasa Terhadap Keputusan Mahasiswa Memilih Perguruan Tinggi Negeri. BALANCA: Jurnal Ekonomi dan Bisnis Islam, 1(1), 110-132.
} 
muncul dalam tanggapan terhadap strategi yang dapat berkembang melalui sebuah proses perumusan (formulation) yang di ikuti oleh pelaksanaan (implementation). ${ }^{8}$

Strategi adalah suatu alat yang digunakan untuk mencapai tujuan perusahaan serta pemakaian cara-cara dan alokasi sumber-sumber yang diperlukan untuk mencapai tujuan. ${ }^{9}$ Strategi juga bisa diartikan sebagai pemimpin, yaitu suatu yang dikerjakan oleh para pengusaha dalam membuat rencana untuk menghadapi persaingan dan memenangkan pangsa pasar di dunia ekonomi. ${ }^{10}$

Pemasaran adalah salah satu kegiatan dalam perekonomian yang membantu dalam menciptakan nilai ekonomi. Nilai ekonomi itu sendiri menentukan harga barang dan jasa. Faktor penting dalam menciptakan nilai tersebut adalah produksi, pemasaran, konsumsi, dan mengomersialisasikan relasi dengan konsumen untuk jangka panjang. Pemasaran menjadi penghubung antara kegiatan produksi dan konsumsi. Definisi pemasaran ini berdasar pada konsep inti yang meliputi kebutuhan (needs), keinginan (wants), dan permintaan (demands). ${ }^{11}$

Pemasaran (marketing) adalah suatu proses kegiatan sosial, budaya, politik, ekonomi dan manajerial.12 Menurut Kotler, yang dikutip oleh Herry Sutanto dan Khaerul Umam menjelaskan bahwa pemasaran sebagai sebuah proses sosial dan manajerial, yang di dalamnya individu dan kelompok mendapatkan apa yang mereka butuhkan dan inginkan melalui penciptaan, penawaran, dan pertukaran produk-produk dengan pihak lainnya. ${ }^{13}$ Menurut Bygrave dalam bukunya yang berjudul The Portable MBA in Enterpreneurship yang telah diterjemahkan kedalam tujuh belas bahasa, yang dikutip oleh

8Usi Usmara, Pemikiran Kreatif Pemasaran, (Yogyakarta: Amara Book, 2008), h. 27. ${ }^{9}$ Supriono, Manajemen Strategi dan Kebijakan Bisnis, (Yogyakarta: BPFE, 1985), 8.

${ }^{10}$ Imam Nawawi, Manajemen Strategi Sektor Publik, (Jakarta: CV. Dwi Pustaka Jaya, 2010), h.3.

${ }^{11}$ Nurul Huda, dkk, Pemasaran Syariah teori dan aplikasi.., h. 5

${ }^{12}$ Freddy Rangkuti, Analisis SWOT Teknik Membedah Kasus Bisnis, (Jakarta: PT Gramedia Pustaka Utama), 2006, h. 48.

${ }^{13}$ Herry Sutanto dan Khairul Umam, Manajemen Pemasaran Bank Syariah..., h. 37. 
Muhammad Ismail Yusanto dan Muhammad Karebet Widjajakusuma, bahwa strategi pemasaran adalah suatu rencana yang efektif dalam bidang pemasaran (produk, harga, promosi, dan distribusi) dengan adanya peluang pasar sasaran yang bertujuan untuk mencapai tujuan suatu usaha. ${ }^{14}$

Strategi pemasaran pada dasarnya adalah rencana yang menyeluruh, terpadau dan menyatu dibidang pemasaran yang memberikan panduan tentang kegiatan yang akan dijalankan untuk dapat tercapainya tujuan pemasaran dari suatu perusahaan. Dengan kata lain strategi pemasaran adalah serangkaian tujuan atau sasaran, kebijakan dan aturan yang memberi arah kepada usaha-usaha pemasaran perusahaan dari waktu ke waktu, pada masing-masing tingkatan dan acuan serta alokasinya, terutama sebagai tanggapan perusahaan dalam menghadapi lingkungan dan keadaan persaingan yang selalu berubah. ${ }^{15}$

Strategi pemasaran terfokus pada mencari dan memberi kepada pelanggan superior, serta memiliki nilai yang berbeda untuk mengembangkan bisnis. Strategi pemasaran juga bertujuan untuk meningkatkan penjualan, karena penjulan merupakan ujung tombak dari strategi yang diterapkan di sebuah perusahaan. Strategi pemasaran harus didasarkan atas analisa lingkungan dan internal perusahaan melalui analisa keunggulan dan kelemahan perusahaan, serta analisa kesempatan dan ancaman yang akan dihadapi perusahaan dari lingkungannya. Selain itu strategi yang telah dijalankan harus dinilai kembali, apakah masih sesuai dengan kondisi saat ini.

Faktor lingkungan yang dianalisa dalam penyusunan strategi pemasaran adalah keadaan pasar atau persaingan, perkembangan teknologi, keadaan ekonomi, peraturan dan kebijakan pemerintah, keadaan sosial budaya dan keadaan politik. Masing-masing faktor ini dapat menimbulkan adanya kesempatan atau hambatan bagi pemasaran produk suatu

${ }^{14}$ Muhammad Ismail Yusanto dan Muhammad Karebet Widjajakusuma, Menggagas Bisnis Islam, (Jakarta: Gema Insani Press, 2002), h. 169.

15Sofjan Assauri, Manajemen Pemasaran, (Jakarta: Rajawali Pers, 2015), h. 154. 
perusahaan. Khusus dalam bidang pemasaran, faktor lingkungan atau eksternal adalah faktor yang tidak dapat dikendalikan oleh pimpinan perusahaan. Sedangkan faktor internal dalam bidang pemasaran adalah faktor yang dapat dikendalikan oleh pimpinan perusahaan umumnya dan pimpinan pemasaran khususnya, yang terdiri dari produk, harga, distribusi, promosi dan pelayanan. ${ }^{16}$

Kotler menyebutkan bahwa konsep bauran pemasaran terdiri dari empat P (4P), yaitu: Product (produk), Price (harga), Place (empat), Promotion (promosi). Sedangkan menurut Boom dan Bitner yang dikutip oleh Buchari Alma menambahkan dalam bisnis jasa, yaitu: People (orang), Physical evidence (fasilitas fisik), Process (proses) ${ }^{17}$. Dari penjelasan tadi dapat disimpulkan bahwa secara keseluruhan penggunaan konsep bauran pemasaran untuk produksi jasa jika digabungkan menjadi 7P, yaitu: Product (produk), Price (harga), Place (tempat), Promotion (promosi), People (orang), Physical evidence (fasilitas fisik), Process (proses). Adapun penjelasan 7P menurut Kotler dan Amstrong ${ }^{18}$ adalah sebagai berikut:

\section{1) Product (produk)}

Menurut pendapat Philip Kotler, produk adalah sesuatu yang dapat ditawarkan ke pasar untuk mendapatkan perhatian untuk dibeli, untuk digunakan, atau dikonsumsi sehingga dapat memenuhi keinginan dan kebutuhan masyarakat.

Sedangkan menurut Ikatan Bankir Indonesia menjelaskan bahwa produk adalah sesuatu yang memberikan manfaat, baik dalam hal memenuhi kebutuhan sehari-hari atau sesuatu yang ingin dimiliki oleh konsumen. Untuk memenuhi keinginan dan kebutuhan akan produk tersebut, maka

${ }^{16}$ Sofjan Assauri, Manajemen Pemasaran..., h. 154-155.

${ }^{17}$ Boom, Bitner yang dikutip oleh Buchari Alma. 2002, Bauran Pemasaran, Diakses http://repository.usu.ac.id/bitstream/123456789/17054/3/Chapter\%20II.pdf, pada 1 Juli 2019.

${ }^{18}$ Philip Kotler dan Gary Armstrong, Prinsip-prinsip Pemasaran, Edisi 12, Jilid 1, Terjemahan Bob Sabran, (Jakarta: Erlangga, 2012), h. 62. 
konsumen harus mengorbankan sesuatu sebagai balas jasanya, seperti dengan cara pembelian menggunakan uang. ${ }^{19}$

Dalam bauran pemasaran, produk merupakan unsur yang paling penting karena dapat mempengaruhi strategi pemasaran lainnya. Pemilihan jenis produk yang akan dihasilkan dan dipasarkan akan menentukan kegiatan promosi yang dibutuhkan, serta penentuan harga dan cara penyalurannya. ${ }^{20}$

Rasulullah saw. dalam usaha perdagangannya selalu memberikan contoh untuk memisahkan barang yang bagus dengan barang yang buruk, karena beliau tidak ingin merugikan dan mengecewakan pelanggannya, sehingga dapat menghilangkan kepercayaan pelanggan tersebut. Seperti klasifikasi produk Rasulullah yaitu barang yang bagus dijual dengan harga yang mahal dan barang yang kualitasnya lebih rendah dijual dengan harga yang lebih rendah. ${ }^{21}$

2) Price (Harga)

Harga adalah salah satu bagian dari bauran pemasaran yang menghasilkan pendapatan, sedangkan bagian lain menghasilkan biaya. Harga merupakan elemen termudah dalam program pemasaran untuk bisa disesuaikan pada fitur produk, saluran, dan bahkan komunikasi membutuhkan lebih banyak waktu. Produk yang dirancang dan dipasarkan dengan baik, dapat dijual dengan harga tinggi dan menghasilkan laba yang besar. Harga sangat penting untuk diperhatikan, karena harga sangat menentukan laku tidaknya produk dan jasa perbankan. ${ }^{22}$

Rasulullah saw. adalah seorang pedagang yang jujur sehingga mendapatkan julukan As-Shaduq Al-Mashduq (orang yang sangat jujur dan dapat dibenarkan). Dalam hal berdagang, beliau selalu jujur kepada

\footnotetext{
${ }^{19}$ Kasmir, Pemasaran Bank..., h. 122.

${ }^{20}$ Sofjan Assauri, Manajemen Pemasaran..., h. 200.

${ }^{21}$ Mokh. Syaiful Bakhri dan Abdussalam, Sukses Berbisnis ala Rasulullah saw...., (Jakarta: Erlangga, 2012), h. 82.

${ }^{22}$ Mokh. Syaiful Bakhri dan Abdussalam, Sukses Berbisnis ala Rasulullah saw......., h. 135
} 
pelanggannya, beliau memasarkan produknya dengan menjelaskan harganya diawal tanpa adanya kebohongan, penipuan yang mengakibatkan pelanggan kecewa, sehingga menimbulkan permusuhan dan percekcokan. ${ }^{23}$

3) Place (tempat)

Lokasi adalah tempat di mana diperjualbelikan produk cabang bank dan pusat pengendalian perbankan. Lokasi pada produk dan jasa bank lebih didominasi jaringan kantor meski didukung oleh ATM, internet banking, phone banking, mobile banking, mobile branch, serta lewat pihak ketiga seperti kantor pos. Fungsi kantor masih menjadi contact point di beberapa Negara maju yang telah memanfaatkan sumber daya teknologi informasi. Dalam menentukan lokasi kantor, ATM, dan CDM harus berada di titik keramaian, seperti perumahan, perkantoran, kawasan industri, pusat perbelanjaan, dan kawasan pendidikan. ${ }^{24}$

\section{4) Promotion (Promosi)}

Promosi merupakan satu upaya untuk menawarkan barang dagangan kepada calon pembeli. Kegiatan promosi produk dan jasa bank lebih baik dilakukan lewat media massa cetak dan audiovisual, seperti: majalah, surat kabar, dan televisi. Promosikanlah barang atau produk dengan cara yang paling tepat, sehingga dapat menarik minat calon pembeli. Faktor tempat dan cara menawarkan produk harus disajikan dengan cara yang menarik juga.

\section{5) People (orang)}

Orang merupakan asset utama dalam industri jasa, yang merupakan karyawan dengan performance tinggi. Orang adalah seseorang yang terlibat aktif dalam pelayanan dan memengaruhi persepsi pembeli, nama, pribadi pelanggan, dan pelanggan-pelanggan lain yang ada dalam lingkungan pelayanan.

${ }^{23}$ Mokh. Syaiful Bakhri, dan Abdussalam, Sukses Berbisnis ala Rasulullah saw......., h. 78.

${ }^{24}$ Ikatan Bankir Indonesia, Strategi Bisnis Bank Syariah (Jakarta: Gramedia Pustaka Utama,

2015), h. 133. 
Dalam praktik perbankan melalui face to face kepada nasabah, maka karyawan harus menunjukkan penampilan yang ramah dan menarik serta memiliki kapasitas TASK (Talent, Attitude, Skill, and Knowledge). Setiap bank syariah harus memiliki motif berkiprah untuk ibadah dalam rangka berdakwah, menguasai operasional perbankan, memahami prinsip syariah yang menjadi fundamental bisnis. ${ }^{25}$

Menarik seorang pelanggan memang sulit, tetapi mempertahankannya justru lebih sulit. Nabi Saw selalu melayani pelanggannya dengan ikhlas sepenuh hati, beliau tidak rela jika pelanggannya tertipu dan kecewa ketika membeli barang dagangannya.

Jika pelayanan yang kita berikan kepada nasabah dapat memuaskan, maka nasabah juga akan mempercayai kita dan akan terus berlangganan produk yang kita tawarkan. Dan sebaliknya, letak kepuasan nasabah di tingkat yang lebih tinggi. Kunci dalam pemasaran adalah memberikan kepuasan kepada pelanggan. ${ }^{26}$

\section{6) Physical Evidence (bukti fisik)}

Salah satu unsur yang paling penting dalam menawarkan produk perusahaan adalah dengan menawarkan bukti fisik dari karakteristik barang atau produk. Bukti fisik ini memiliki karakteristik yang menjadi persyaratan bernilai tambah bagi konsumen dalam perusahaan jasa yang memiliki karakter. Bukti fisik setiap titik kontrak harus bagus, menarik, nyaman, dan aman sehingga nasabah atau orang yang berkunjung merasa seperti rumah sendiri, dengan dukungan dekorasi, layout ruangan, aroma ruangan, dan kenyamanan ruangan. ${ }^{27}$

7) Process (proses)

Proses berjalannya bisnis harus efektif dan efisien, Karena sangat berpengaruh terhadap produktivitas dan penghematan biaya. Proses di sini

\footnotetext{
25Ikatan Bankir Indonesia, Strategi Bisnis Bank Syariah,..h. 134

${ }^{26}$ Mokh. Saiful Bakhri dan Abdussalam, Sukses Berbisnis ala Rasulullah saw......., h. 8081.

27Ikatan Bankir Indonesia, Strategi Bisnis Bank Syariah..., h. 135.
} 
berkaitan dengan proses berjalannya pelayanan yang diberikan kepada konsumen selama melakukan pembelian barang. Proses yang dijalankan sangat terkait dengan standard of result yang dijanjikan kepada nasabah, standard of process, dan standard of behavior yang dijadikan acuan praktik.

\section{Produk Pembiayaan PT. BNI Syariah KC. Parepare}

Dua fungsi utama bank syariah adalah mengumpulkan dana dan menyalurkan dana. Penyaluran dana yang dilakukan Bank Syariah adalah pemberian pembiayaan kepada debitur yang membutuhkan, baik untuk modal usaha, investasi maupun konsumsi.28

Istilah pembiayaan pada dasarnya lahir dari pengertian kata I Believe, I Trust, yaitu saya percaya atau saya menaruh kepercayaan. Perkataan pembiayaan yang berarti kepercayaan yang berarti bank menaruh perhatian kepada seseorang untuk melaksanakan amanah yang diberikan oleh bank selaku shohibul maal. Dana tersebut harus digunakan dengan benar, adil dan harus disertai dengan ikatan dan syarat-syarat yang jelas serta saling menguntungkan bagi kedua belah pihak. ${ }^{29}$ Menurut sifat penggunaannya, pembiayaan dapat dibagi menjadi dua hal sebagai berikut : ${ }^{30}$

(1) Pembiayaan produktif, yaitu pembiayaan yang ditujukan untuk memenuhi kebutuhan produksi dalam arti luas, yaitu peningkatan usaha, baik usaha produksi, perdagangan maupun investasi.

(2) Pembiayaan konsumtif, yaitu pembiayaan yang digunakan untuk memenuhi kebutuhan konsumsi, yang akan habis digunakan untuk memenuhi kebutuhan.

Dalam hal ini, pembiayaan yang dimaksud adalah pembiayaan produktif untuk usaha yang dikenal dengan pembiayaan BNI Syariah. Produk

28Muhamad, Manajemen Bank Syariah,(Yogyakarta: UPP STIM YKPN, 2011), h.303.

${ }^{29}$ Veithzal Rivai, Arviyan Arifin, Islamic Banking: sebuah Teori, knsep, dan Aplikasi, (Jakarta: PT Bumi Aksara, 2010), h. 698.

${ }^{30}$ Muhamad Syafi'I Antonio, Bank Syari'ah: Dari Teori Ke Praktek, (Jakarta: Gema Insani Press, 2001), h. 160. 
pembiayaan BNI syariah kini menjadi solusi bagi pelaku usaha mikro yang sedang membutuhkan modal usaha, sehingga banyak dari pengusaha yang menggunakan penawaran ini. Pengusaha dapat meminjam sejumlah dana sesuai dengan kebutuhan dan ketentuan yang berlaku.

Produk Pembiayaan di PT. BNI Syariah KC. Parepare ada 4 jenis berdasarkan plafondnya yaitu pembiayaan mikro yang terdiri dari mikro 2 iB Hasanah, dan mikro 3 iB Hasanah, serta pembiayaan usaha kecil dan menengah yang terdiri dari Wirausaha iB Hasanah (WUS), dan kemudian muncul lagi satu produk baru yaitu produk pembiayaan produktif Usaha Kecil iB Hasanah. Sebagaimana penjelasan Bapak Nirwan Alimuddin selaku Micro Sales Business Head PT. BNI Syariah KC. Parepare berikut:

Produk pembiayaan di kami terdiri dari tiga, baru beberapa bulan terakhir ini muncul produk baru yaitu produktif. Jadi produk pembiayaan mikro itu terbagi menjadi tiga berdasarkan plafondnya, plafond itu maksudnya nominal angka yang bisa dibiayai. Rp. 5 juta sampai dengan Rp. 50 juta disebut mikro 2, Rp. 51 juta sampai dengan Rp. 500 juta disebut mikro 3, Rp. 501 juta atau lebih dari Rp. 500 juta sampai dengan Rp. $1 \mathrm{M}$ itu disebut WUS. ${ }^{31}$

Berikut penjelasannya selengkapnya mengenai Produk Pembiayaan di PT. BNI Syariah KC. Parepare:

a. Pembiayaan Mikro 2 iB Hasanah

Pembiayaan mulai dari Rp. 5 juta hingga Rp. 50 juta jangka waktu pembiayaan mulai 6 bulan hingga 36 bulan. Tujuan pembiayaan adalah pembelian barang modal kerja, Investasi produktif dan pembelian barang lainnya (konsumtif). Adapun persyaratan yaitu Fotokopi KTP, Kartu Keluarga (KK), Surat Keterangan Usaha, dan Bukti Kepemilikan Jaminan. ${ }^{32}$ Adapun segmen pasar dari Pembiayaan Mikro 2 iB Hasanah ini yaitu seperti para pedagang di kios dan lapak-lapak dalam pasar yang telah mendapat ijin analisa pasar dari manajemen PT. BNI Syariah KC. Parepare. Sebagaimana

\footnotetext{
31Nirwan Alimuddin, "Micro Sales Business Head PT. BNI Syariah KC. Parepare," Wawancara, Parepare, 18 Juli 2019.

32 BNI Syariah, Miko 2 iB Hasanah, https://www.bnisyariah.co.id/idid/personal/pembiayaan/mikro/mikro2ibhasanah
} 
yang dijelaskan oleh Nirwan Alimuddin seorang Micro Sales Business Head berikut:

Berdasarkan klasifikasi dari ketiga plafond ini, segmentasi pasarnya tentu beda. Kalau kita lihat plafond Rp. 5 juta sampai Rp. 50 juta kita bisa masuk di dalam pasar seperti lapak-lapak. ${ }^{33}$

b. Pembiayaan Mikro 3 iB Hasanah

Dana yang dapat di pinjam melalui pembiayaan mulai dari lebih dari Rp. 50 juta hingga Rp. 500 juta. Jangka waktu dapat dipilih sesuai kebutuhan dan kemampuan mulai 6 bulan hingga 60 bulan. Tujuan dari pembiayaan ini antara lain untuk pembelian barang modal kerja, investasi produktif dan pembelian barang lainnya (konsumtif). Persyaratannya yaitu Fotokopi KTP, Kartu Keluarga (KK), Surat Keterangan Usaha, dan Bukti Kepemilikan Jaminan. ${ }^{34}$ Adapun segmen pasar Pembiayaan Mikro 3 iB Hasanah ini seperti para pengusaha pemilik ruko-ruko dan toko-toko di sekitar pinggiran luar pasar Lakessi, dengan radius kurang lebih $20 \mathrm{Km}$ dari kantor PT. BNI Syariah KC. Parepare. Sebagaimana yang dijelaskan oleh Nirwan Alimuddin seorang Micro Sales Business Head berikut:

Kalau mikro 3 kebanyakan yang ambil dikami Rp. 51 juta sampai dengan Rp. 500 juta itu adalah para pengusaha di pnggir-pinggir pasar, seperti ruko-ruko dan toko-toko yang masih berada dalam radius market maksimal $20 \mathrm{Km}$ dari kantor. ${ }^{35}$

c. Pembiayaan Wirausaha iB Hasanah (WUS)

Wirausaha iB Hasanah (WUS) adalah fasilitas pembiayaan produktif yang ditujukan untuk memenuhi kebutuhan pembiayaan usaha-usaha produktif (modal kerja dan investasi) yang tidak bertentangan dengan syariah dan ketentuan peraturan perundangan yang berlaku.

Segemen pasarnya yaitu para pengusaha yang sudah berbentuk industri yang sudah memiliki neraca keuangan dan transaksinya sudah

\footnotetext{
${ }^{33}$ Nirwan Alimuddin, "Micro Sales Business Head PT. BNI Syariah KC. Parepare," Wawancara, Parepare, 18 Juli 2019.

34 BNI Syariah, Miko 3 iB Hasanah, https://www.bnisyariah.co.id/idid/personal/pembiayaan/mikro/mikro3ibhasanah

${ }^{35}$ Nirwan Alimuddin, "Micro Sales Business Head PT. BNI Syariah KC. Parepare," Wawancara, Parepare, 18 Juli 2019
} 
tercermin di rekening bank. Sebagaimana yang dijelaskan oleh Nirwan Alimuddin seorang Micro Sales Business Head berikut:

Khusus untuk WUS dengan plafond diatas Rp. 500 juta sampai dengan Rp. $1 \mathrm{M}$, segmennya yaitu para pengusaha yang sudah berbentuk industri, dengan kebutuhan yang besar, kebanyakan mereka sudah punya neraca keuangan, pembukuan sudah lengkap, dan syarat utamanya adalaha transaksi keuangan dari usaha tersebut sudah tercermin di rekening bank. ${ }^{36}$

d. Pembiayaan Produktif Usaha Kecil iB Hasanah

Usaha Kecil iB Hasanah adalah pembiayaan syariah yang digunakan untuk tujuan produktif (modal kerja maupun investasi) kepada pengusaha kecil berdasarkan prinsip-prinsip pembiayaan syariah.

Produk Pembiayaan Produktif Usaha Kecil iB Hasanah, belum berjalan di Kota Parepare, artinya belum terdapat nasabah yang mengambil pembiayaan ini, akan tetapi tetap akan dijalankan ketika terdapat nasabah yang membutuhkannya. Sebagaimana yang diungkapkan oleh bapak Nirwan Alimuddin selaku Micro Sales Business Head PT. BNI Syariah KC. Parepare berikut:

Untuk di Parepare sendiri kami baru bisa mengcover tiga macam pembiayaan ini, tapi misalnya di lapangan kami dapati plafond diatas Rp. 1 Milyar, maka kami akan proses, dan sampai saat ini di Parepare memang belum ada khusus untuk nasabah pembiayaan usaha produktif. ${ }^{37}$

Khusus untuk penentuan target pasar pembiayaan usaha PT. BNI Syariah, tidak semua pengusaha di Kota Parepare yang bisa dijadikan target pasar, akan tetapi hanya pengusaha yang memenuhi syarat saja berdasarkan analisa pasar dari manajemen PT. BNI Syariah KC. Parepare. Hal ini sebagaimana diungkapkan oleh Bapak Nirwan Alimuddin selaku Micro Sales Business Head PT. BNI Syariah KC. Parepare berikut:

Jadi tidak semua pasar kami biayai, harus ada analisa pasar terlebih dahulu. Jadi, semua kios-kios dan lapak-lapak yang ada di pasar itu yang

\footnotetext{
36Nirwan Alimuddin, "Micro Sales Business Head PT. BNI Syariah KC. Parepare," Wawancara, Parepare, 18 Juli 2019.

${ }^{37}$ Nirwan Alimuddin, "Micro Sales Business Head PT. BNI Syariah KC. Parepare," Wawancara, Parepare, 18 Juli 2019.
} 
sudah mendapatkan analisa pasar dari manajemen kami itu bisa kami biayai sesuai dengan kebutuhan dan kemampuan masing-masing.38

Masing-masing Produk Pembiayaan di PT. BNI Syariah KC. Parepare range plafond yang memang disesuaikan dengan kebutuhan konsumen pengusaha atau nasabah. Akan tetapi, tidak menutup kemungkinan pengusaha yang kategori mikro 3 IB Hasanah misalnya, kebutuhannya hanya pada produk mikro 2 IB Hasanah, maka akan tetap diproses pembiayaannya, karena faktor pemilihan produk pembiayaan oleh pengusaha atau nasabah salah satunya berdasarkan kebutuhan dan kemampuannya. Hal ini sebagaimana dijelaskan oleh Bapak Nirwan Alimuddin selaku Micro Sales Business Head PT. BNI Syariah KC. Parepare berikut:

Tidak tertutup kemungkinan bila ada dari klasifikasi pengusaha yang mampu Rp. 51 juta sampai dengan Rp. 500 juta yang mau ke mikro 2 karena berdasarkan kebutuhan, karena kan kita tidak bisa paksakan ini pengusaha yang segmennya mikro 3, tapi karena kebutuhannya hanya mikro 2, mungkin kebutuhannya hanya Rp. 30 juta, Rp. 40 juta, sampai Rp. 50 juta, itu minatnya hanya ke mikro $2 .{ }^{39}$

Dengan bervariasinya Produk Pembiayaan di PT. BNI Syariah KC. Parepare ini akan memberikan kebebasan memilih bagi pengusaha atau nasabah dengan menyesuaikan kebutuhan dan kemampuan mereka. Adapun akad yang digunakan dalam produk pembiayaan ini adalah akad murabahah yaitu akad jual beli. Selain akad murabahah, terdapat pula akad wakalah untuk mengkuasakan nasabah membeli kebutuhan usahanya. Selanjutnya ditambahkan lagi satu akad yaitu akad Musyarakah Mutanaqisyah (MMq). Berikut penjelasan Bapak Nirwan Alimuddin mengenai akad pada pembiayaan usaha di PT. BNI Syariah KC. Parepare:

Akad yang digunakan yaitu akad murabahah atau akad jual beli. Akad murabahah ini setelah dilakukan penandatangan akan ditambahkan lagi satu akad yaitu akad wakalah untuk mengkuasakan. Pada dasarnya BNI Syariah ini hubungan antara bank dengan nasabah bukan kreditur dan debitur, tapi hubungan mitra kerjasama. Melalui kerjasama ini dikeluarkanlah akad MMq ini dengan tujuan keuntungan dan kerugian

\footnotetext{
${ }^{38}$ Nirwan Alimuddin, "Micro Sales Business Head PT. BNI Syariah KC. Parepare," Wawancara, Parepare, 18 Juli 2019.

${ }^{39}$ Nirwan Alimuddin, "Micro Sales Business Head PT. BNI Syariah KC. Parepare," Wawancara, Parepare, 18 Juli 2019.
} 
dibagi, jadi seumpamanya pengusaha untung kita sama-sama untung, sebaliknya jika pengusaha rugi, kita sama-sama rugi. Namun pada dasarnya dari awal sampai sekarang yang berjalan itu adalah akad murabahah, akan MMq ini baru muncul dan belum terlaksana $\cdot 40$

Berbeda dengan di perbankan syariah lain, seperti pada bank Muamalat cabang Makassar dan Unit Usaha Syariah BPD Sulselbar, bahwa produk pembiayaan modal kerja menggunakan akad mudharabah atau bagi hasil. 41

Selain keberagaman jenis Produk Pembiayaan di PT. BNI Syariah KC. Parepare, produk ini juga memiliki beberapa perbedaan dengan produkproduk pembiayaan pada umumnya di bank-bank konvensional. Seperti tidak adanya biaya administrasi, hanya biaya pihak ketiga yaitu untuk notaris dan asuransi. Selain itu dalam produk ini juga tidak terdapat biaya denda bagi nasabah yang terlambat membayar angsurannya misalnya satu, dua, atau tiga hari. Hal ini sebagaimana yang disampaikan oleh Bapak Nirwan Alimuddin selaku Micro Sales Business Head PT. BNI Syariah KC. Parepare berikut:

Perbedaan yang paling menonjol adalah di BNI Syariah tidak ada biaya administrasi, kebanyakan di bank lain ada biaya appraisal, ada biaya provisi, itu masuk kategori biaya administrasi. Biaya appraisal, dan biaya provisi di kami itu nol rupiah. Kan biasa yang lain ada biaya survei, biaya ini, biaya ini, dikami nol rupiah. Jadi biaya yang ada dikami ini hanya biaya pihak ketiga, yaitu biaya notaris dan biaya asuransi. Di kami juga tidak ada denda, jadi jika ada nasabah yang dalam masa itu kesusahan, lewat angsurannya satu hari, dua hari, kami tidak kenakan denda dan dibayar sesuai angsuran.. ${ }^{42}$

2. Promosi produk pembiayaan PT. BNI Syariah KC. Parepare

Strategi promosi produk pembiayaan PT. BNI Syariah KC. Parepare dengan target pasar yaitu para pengusaha, maka strategi yang digunakan

\footnotetext{
${ }^{40}$ Nirwan Alimuddin, "Micro Sales Business Head PT. BNI Syariah KC. Parepare," Wawancara, Parepare, 18 Juli 2019.

${ }^{41}$ Rahman Ambo Masse, "Implementasi Prinsip Syariah dalam Akad Pembiayaan Perbankan Syariah (Studi pada Bank Muamalat dan Unit Usaha Syariah Bank BPD Sulselbar di Kota Makassar).", Disertasi Doktor (Makassar: Universitas Islam Negeri Alauddin Makassar, 2015, (online) dalam http://repositori.uin-alauddin.ac.id/623/, (diakses pada 11 Oktober 2019).

${ }^{42}$ Nirwan Alimuddin, "Micro Sales Business Head PT. BNI Syariah KC. Parepare," Wawancara, Parepare, 18 Juli 2019.
} 
adalah promosi door to door artinya mempromosikan dari rumah ke rumah pengusaha yang ada di Kota Parepare. Seperti yang dikatakan oleh Bapak Ardianto selaku Micro Sales Assisten PT. BNI Syariah KC. Parepare berikut:

Strategi pemasaran yang kami lakukan adalah strategi door to door. Berkaitan dengan pembiayaan mikro, pasti berkaitan semua dengan pengusaha. Kami jarang ikut sosialisasi di instansi-instansi, karena ratarata di instansi itu PNS, pegawai, karyawan, hanya satu atau dua orang yang punya usaha. Selain target marketnya door to door, biasanya melalui SMS, WhatsApp, Facebook, semua sosial media yang dimanfaatkan untuk mempromosikan produk-produk PT. BNI Syariah KC. Parepare. ${ }^{43}$

Pemanfaatan media sosial sebagai media promosi sangat menunjang lancarnya komunikasi. Untuk memaksimalkan promosi melaui media sosial ini sangat dibutuhkan anggaran promosi. Di PT. BNI Syariah KC. Parepare, anggaran untuk promosi sebenarnya ada, tapi tidak seberapa, anggaran yang besar untuk promosi pada event-event tertentu, tapi hal itu jarang dilakukan. Namun terdapat tunjangan pulsa untuk melakukan promosi melalui sosial media. Hal ini sebagaimana dikatakan oleh Bapak Ardianto selaku Micro Sales Assisten PT. BNI Syariah KC. Parepare berikut:

Untuk anggaran khusus promosi sebenarnya ada, tapi hanya untuk event-event tertentu, itupun agak-agak jarang. Cuma kalau untuk tunjangan pulsa ada, untuk sosial media, dimanfaatkan untuk telepon, komunikasi. ${ }^{44}$

Namun, kasus yang ditemukan di lapangan menunjukkan bahwa kurangnya promosi yang dilakukan kepada pengusaha, hal ini seperti yang dikatakan oleh Bapak H. HR. Lantong penjual kerudung di Pasar Lakessi Parepare berikut:

Saya baru tahu kalau ada BNI Syariah di Jl. Lahalede. Itu karena orang dari sana tidak pernah jalan-jalan ke pasar, kepada pengusaha untuk menawarkan dirinya. Jadi banyak orang yang tidak tahu. Tepatnya mereka kurang promosi.45

${ }^{43}$ Ardianto, “Micro Sales Business PT. BNI Syariah KC. Parepare," Wawancara, Parepare, 18 Juli 2019.

${ }^{44}$ Ardianto, "Micro Sales Business PT. BNI Syariah KC. Parepare," Wawancara, Parepare, 18 Juli 2019.

${ }^{45}$ H. HR. Lantong, "Penjual Kerudung Pasar Lakessi," Wawancara, Parepare, 13 Juli 2019. 
Selain itu pendapat yang sama juga dikemukakan oleh Bapak H. Imran penjual pecah belah di pasar Lakessi Parepare berikut:

Karyawan BNI Syariah memang tidak pernah melakukan promosi disini, hanya BNI 46 yang pernah datang, itupun hanya untuk tabungan. ${ }^{46}$

Terdapat pula pendapat Andi Haswan salah satu pengusaha pemilik Pettalolo Cafe di Parepare mengatakan bahwa:

Kurangnya promosi yang dilakukan oleh karyawan BNI Syariah membuat saya tidak tahu bahwa ada Produk Pembiayaan disana. ${ }^{47}$

Pendapat-pendapat pengusaha ini merupakan pengusaha non nasabah PT. BNI Syariah KC. Parepare. Namun terdapat pula pendapat dari Bapak Fiqhuddin salah satu pengusaha yang sudah menjadi nasabah dari Produk Pembiayaan di PT. BNI Syariah KC. Parepare berikut:

Karyawannya sering melakukan promosi, seperti door to door. ${ }^{48}$

Ibu Hj. Andi Fatimah selaku nasabah dari Produk Pembiayaan di PT. BNI Syariah KC. Parepare juga mengatakan bahwa:

Karyawan dari BNI Syariah langsung mengunjungi saya dan mempromosikan produknya, serta menawarkannya. Dan akhirnya saya menjadi nasabah sejak tahun 2015 sampai sekarang. Setiap ada produk baru saya selalu diinformasikan melalui telepon ataupun sosial media. ${ }^{49}$

Perbedaan pendapat ini sebenarnya bisa terjawab berdasarkan pemaparan sebelumnya oleh Bapak Nirwan Alimuddin Selaku Micro Sales Business Head PT. BNI Syariah KC. Parepare bahwa tidak semua pasar atau pengusaha dapat dibiayai, akan tetapi hanya pengusaha yang telah mendapatkan ijin dari manajemen analisa pasar. Hal ini dimaksudkan untuk mengurangi risiko adanya nasabah-nasabah yang tidak amanah. Jadi, jika pengusaha yang tidak didatangi untuk ditawarkan Produk Pembiayaan di PT. Juli 2019 .

${ }^{46}$ H. Imran, "Stand H. Imran Pecah Belah Pasar Lakessi," Wawancara, Parepare, 29

${ }^{47}$ Andi Haswan, "Pettalolo Cafe," Wawancara, Parepare, 16 Juli 2019.

48Fiqhuddin, "UD. Soreang Motor," Wawancara, Parepare, 29 Juli 2019.

${ }^{49} \mathrm{Hj}$. Andi Fatimah,"Emerald (Kosmetik)," Wawancara, Parepare, 28 Juli 2019. 
BNI Syariah KC. Parepare, berarti belum memiliki ijin dari manajemen analisa pasar PT. BNI Syariah.

3. Karyawan PT. BNI Syariah KC. Parepare

Salah satu peranan penting karyawan dalam suatu instansi perbankan yaitu pemberian layanan kepada nasabah. Berhubungan dengan strategi pemasaran, karyawan yang memegang tanggung jawab paling besar yaitu Micro Sales Assisten atau asistem pemasaran. Mereka harus memilki strategistrategi tersendiri guna membangun citra dalam masyarakat, khususnya para pengusaha untuk memperoleh simpati. Pemberian layanan yang memadai, komunikasi yang efektif, dan hubungan silaturrahmi yang terjaga dapat memberikan kemudahan kepada karyawan untuk memperoleh simpati dari calon nasabah. Salah satu strategi layanan yang biasanya digunakan oleh para Micro Sales Assisten PT. BNI Syariah KC. Parepare yaitu kunjungan kepada nasabah untuk menjalin silaturahmi terlebih dahulu. Sebagaimana yang diungkapkan oleh Bapak Ardianto selaku Micro Sales Assisten PT. BNI Syariah KC. Parepare berikut:

Kalau saya secara pribadi, yaitu sering-sering melakukan kunjungan kepada nasabah. Bahkan walaupun belum menjadi mitra BNI Syariah, saya terkadang singgah bersilaturrahmi, minimal ada hubungan yang terjaga, minimal dia tahu, karena tidak mesti mereka harus bekerjasama dengan BNI Syariah baru kita kenalan, karena misalkan sewaktu-waktu kita punya kebutuhan yang lain, dan tiba-tiba mereka juga punya kebutuhan, pasti paing tidak BNI Syariah yang mereka ingat ketika mereka ada kebutuhan, apalagi dari sisi pembiayaan. ${ }^{50}$

Pernyataan tersebut dapat didukung oleh beberapa pernyataan pengusaha yang sudah menjadi nasabah Produk Pembiayaan PT. BNI Syariah sebagai berikut:

Kayawan marketing PT. BNI Syariah sering datang bekunjung kesini memberikan informasi-informasi mengenai produk-produknya, atau sekedar berkunjung untuk bersilaturrahmi, bahkan sudah ada beberapa yang menjadi pelanggan saya. ${ }^{51}$

${ }^{50}$ Ardianto, “Micro Sales Business PT. BNI Syariah KC. Parepare," Wawancara, Parepare, 18 Juli 2019.

51Hj. Andi Fatimah,"Emerald (Kosmetik)," Wawancara, Parepare, 28 Juli 2019. 
Namun, masih banyak pengusaha yang belum menjadi nasabah mengatakan bahwa karyawan PT. BNI Syariah KC. Parepare jarang melakukan kunjungan bahkan tidak pernah sama sekali. Berikut beberapa pendapat pengusaha:

Saya tidak pernah dikunjungi oleh karyawan BNI Syariah untuk menawarkan produknya. ${ }^{52}$

Saya nasabah di BNI Syariah, tapi hanya menabung saja, saya tidak pernah dikunjungi untuk ditawarkan Produk Pembiayaannya. ${ }^{53}$

Dari beberapa pernyataan diatas, dapat dilihat bahwa kunjungan yang dilakukan oleh karyawan khususnya marketing masih kurang dilakukan kepada beberapa pengusaha-pengusaha yang ada di kota Parepare. Sehingga kunjungan tersebut dapat ditingkatkan lagi guna mendapatkan informasi lebih banyak mengenai calon nasabah. Apabila setelah dilakukan kunjungan ternyata tidak sesuai dengan analisa pasar, setidaknya sudah memperkenalkan diri kepada pengusaha bahwa di PT. BNI Syariah KC. Parepare terdapat beberapa produk pembiayaan.

Selain layanan yang bersifat kunjungan, hal yang harus dimiliki oleh karyawan perbankan syariah salah satunya adalah kompetensi dibidang perbankan syariah, seperti harus memiliki motif berkiprah untuk ibadah dalam rangka berdakwah, menguasai operasional perbankan syariah, memahami prinsip syariah yang menjadi fundamental bisnis.

Kompetensi tersebut setidaknya sudah dimiliki oleh beberapa karyawan PT. BNI Syariah KC. Parepare, hal ini ditunjukkan oleh pernyataan salah seorang karyawan PT. BNI Syariah KC. Parepare sebagai berikut:

Karena kita fokus utamanya adalah dakwah, business follow (bisnis mengikuti), adapun yang tidak bisa menerima dakwah, kita ceritakan lagi keunggulan-keunggulan di BNI Syariah, dan produk-produknya seperti apa?. ${ }^{4}$

52Rachma, "Fitra Tailor," Wawancara, Parepare, 12 Juli 2019.

${ }^{53}$ Baharuddin, "Home Cake," Wawancara, Parepare, 12 Juli 2019.

${ }^{54}$ Ardianto, "Micro Sales Business PT. BNI Syariah KC. Parepare," Wawancara, Parepare, 18 Juli 2019. 
Kebanyakan karyawan perbankan syariah merupakan adopsi dari perbankan konvensional, sehingga mereka masih kurang memahami prinsipprinsip syariahnya, prinsip-prinsip jenis akad yang digunakan, serta prosesproses yang ada diperbankan syariah. Hal tersebut membuat mereka sulit untuk menjelaskan kepada calon nasabah mengenai perbedaan dari sistem perbankan syariah dengan perbankan konvensional. Apalagi ketika menghadapi tantangan dengan nasabah yang sudah terbiasa dengan polapola perbankan konvensional. Kendala dalam menghadapi nasabah tersebut seperti yang dikatakan oleh Bapak Ardianto selaku Micro Business Assisten PT. BNI Syariah KC. Parepare berikut:

Kalau kendala dalam pemasaran yaitu masih banyak masyarakat yang betul-betul belum bisa menerima hijrah atau syariah, yang masih sering dengan pola konvensional, dengan selalu melihat mana yang lebih murah. Nah itulah yang menjadi tantangan bagi karyawan BNI Syariah untuk meyakinkan nasabah. ${ }^{55}$

Tantangan tersebut dibenarkan oleh pernyataan dari beberapa pengusaha mengenai perbedaan perbankan syariah dengan perbankan konvensional. Berikut beberapa pernyataan pengusaha:

Tidak ada bedanya bank syariah dengan bank konvensional, cuma namanya saja beda. Di bank syariah juga pasti pakai bunga, mana mungkin tidak pakai bunga. Walaupun dia tidak pakai bunga, tapi tetap mahal dibandingkan dengan KUR. ${ }^{56}$

Hemat penulis secara pribadi, bahwa antara produk yang ada pada bank syariah dan bank konvensional sangat berbeda, baik dari segi jenis produk dan prosesenya. Untuk menghadapi kendala-kendala seperti nasabah yang tidak dapat menerima anjuran untuk berhijrah ke produk yang syariah, maka harus diberikan dakwah secara lemah lembut.

Penyampaian sesuatu dengan lemah lembut guna menunjukkan simpati. Ini tentu saja bukan berarti bahwa juru dakwah tidak melakukan kritik, hanya saja itu pun harus disampaikan dengan tepat bukan saja pada

${ }^{55}$ Ardianto, “Micro Sales Business PT. BNI Syariah KC. Parepare," Wawancara, Parepare, 18 Juli 2019.

56H. Sena, "Penjual Sayuran Pasar Lakessi," Wawancara, Parepare, 14 Juli 2019. 
kandungannya tetapi juga waktu dan tempatnya serta susunan kata-katanya, yakni tidak memaki dan memojokkan. ${ }^{57}$

Di sisi lain, jika perintah dakwah tersebut telah dilaksanakan dan ditolak maka penolakan itu akan menjadi bukti yang memberatkan sasaran dakwah, karena jika tidak ada ajakan, maka boleh jadi di hari kemudian kelak, mereka akan berkata: "Kami tidak mengetahui tuntunan-Mu, karena tidak ada yang pernah menyampaikannya kepadaa kami."58

Berdasarkan penafsiran di atas, maka salah satu kewajiban dari karywan PT. BNI Syariah KC. Parepare adalah menyampaikan dakwah ajakan kepada pengusaha untuk beralih ke produk yang berbasis syariah.

Akan tetapi bagi pengusaha yang mudah mengerti dapat dengan mudah menerima perbedaan dari perbankan syariah dengan bank konvensional, berikut beberapa pendapat pengusaha yang dapat membedakan antara perbankan syariah dengan perbankan konvensional:

Bank syariah bagus, tapi hampir sama dengan bank konvensional, cuma caranya beda, dia pakai sistem bagi keuntungan, tidak pakai sistem bunga, tapi pada umumnya sama, namanya saja yang beda. 59

Kalau secara sistem akad, bank syariah lebih aman, jauh dari riba, kalau bank konvensional sudah jelas riba, dari awalnya saja sudah riba. Jadi selalu berusaha memulai dari yang halal. ${ }^{60}$

Untuk menghadapi tantangan-tantangan seperti itu, maka dibutuhkan sumber daya manusia yang benar-benar mampu menguasai perbankan syariah, mampu menjelaskan dan meyakinkan kepada calon nasabah maupun nasabah mengenai bank syariah. Apalagi di masa-masa mendatang tantangan akan semakin besar, olehnya itu ada baiknya jika instansi-instansi perbankan syariah merekrut karyawan yang benar-benar memiliki kompetensi dibidang perbankan syariah, seperti misalnya alumni-alumni ..., h. 307.

${ }^{57}$ M. Quraish Shihab, Tafsir Al Misbah: pesan, kesan dan keserasian Al-Qur'an, Volume: 8

${ }^{58}$ M. Quraish Shihab, Tafsir Al Misbah: pesan, kesan dan keserasian Al-Qur'an, Volume: 8 ..., h. 308.

${ }^{59}$ Fiqhuddin, “UD. Soreang Motor,” Wawancara, Parepare, 13 Juli 2019.

${ }^{60}$ Muhammad Wahyu Kurniawan, "Toko Quantum.com," Wawancara, Parepare, 28 Juli 2019. 
dari jurusan perbankan syariah, ekonomi syariah, hukum ekonomi syariah, akuntansi syariah, manajemen syariah, dan masih banyak lagi jurusanjurusan dari perguruan tinggi yang dapat menjadi rujukan dalam merekrut karyawan yang kompeten dibidangnya.

Karyawan-karyawan di PT. BNI Syariah KC. Parepare kurang lebih sudah mampu untuk menciptakan suasana yang sesuai dengan syariah, sudah dapat menjelaskan bagaimana prinsip-prinsip syariah dan sudah dapat menyampaikan dakwah kepada calon nasabah maupun nasabah.

Karyawannya menjelaskan sedikit kepada saya mengenai produknya, selebihnya saya yang mencari informasi sendiri mengenai produk yang saya butuhkan. 61

Karyawannya disana ramah, mereka sering menyampaikan dakwah bahwa lebih baik menggunakan produk bank syariah, lebih aman karena kita tidak hanya hidup untuk di dunia saja, tapi akan dipertanggungjawabkan semuanya di akhirat kelak. ${ }^{62}$

Selain kompetensi yang harus dimiliki oleh karyawan perbankan syariah, penampilan pun tidak boleh diabaikan, terutama bagi karyawan marketing, sebagaimana yang dikatakan oleh Bapak Ardianto selaku Micro Business Assisten PT. BNI Syariah KC. Parepare berikut:

Jadi marketingnya yang harus pintar-pintar menyesuaikan, jika memang nasabahnya mau dalam keadaan yang rapi, formal, otomatis kita juga harus menyesuaikan dalam kadaan formal, rapi, harum. Karena kita bergerak dalam bidang pelayanan, jadi kita juga harus maintanance nasabah supaya bagaimana mereka bisa nyaman sama kita, otomatis kami sebagai marketing kalau pergi dengan bau badan dan sebagainya, naih itu yang harus dijaga agar tidak mengganggu kenyamanan nasabah kepada kita. ${ }^{63}$

Penampilan karyawan saat memberikan pelayanan kepada nasabah harus memperhatikan penampilan, karena walau kelihatan sepele, akan tetapi penampilan karyawan selalu menjadi pandangan pertama bagi nasabah saat akan bertransaksi. 2019.

${ }^{61}$ Muhammad Wahyu Kurniawan, "Toko Quantum.com," Wawancara, Parepare, 28 Juli

${ }^{62} \mathrm{Hj}$. Andi Fatimah,"Emerald (Kosmetik)," Wawancara, Parepare, 28 Juli 2019.

${ }^{63}$ Ardianto, "Micro Sales Business PT. BNI Syariah KC. Parepare," Wawancara, Parepare, 18 Juli 2019. 


\section{Penutup}

Strategi pemasaran produk PT. BNI Syariah KC. Parepare meliputi unsur bauran pemasaran 7P yaitu produk, harga, tempat, promosi, orang/karyawan, fasilitas fisik, dan proses. Dengan menggunakan ketujuh unsur tersebut, strategi pemasaran yang paling efektif yang telah dilakukan di PT. BNI Syariah KC. Parepare adalah strategi promosi dengan cara door to door yang bersifat kunjungan kepada nasabah. Strategi pemasaran produk pembiayaan usaha di PT. BNI Syariah KC. Parepare sesuai dengan prinsip manajemen syariah.

\section{Daftar Pustaka}

Al-Qur'anul Karim

Abdullah, Thamrin dan Francis Tantri. Manajemen Pemasaran. Jakarta: Rajawali Press 2013.

Anoraga, Pandji. Ekonomi Islam Kajian Makro dan Mikro. Yogyakarta: PT. Dwi Chandra Wacana. 2010.

Antonio, Muhammad Syafi'i. Bank Syariah: Dari Teori ke Praktik. Jakarta: Gema Insani Press. 2001.

Assauri, Sofjan. Manajemen Pemasaran. Jakarta: Rajawali Pers. 2015.

Dendawijaya, Lukman. Manajemen Perbankan. Bogor: Penerbit Ghalia Indonesia. 2003.

Hamid, A., \& Zubair, M. K. (2019). Implementasi Etika Islam Dalam Pemasaran Produk Bank Syariah. BALANCA: Jurnal Ekonomi dan Bisnis Islam, 1(1), 16-34.

Huda, Nurul, dkk. Pemasaran Syariah Teori dan Aplikasi. Jakarta: Kencana. 2017.

Ikatan Bankir Indonesia. Strategi Bisnis Bank Syariah. Jakarta: Gramedia Pustaka Utama. 2015.

Ilmi, Makhalul. Teori dan Praktek Mikro Keuangan Syariah. Yogyakarta: UII Press. 2001. 
Ismail. Perbankan Syariah. Jakarta: Penerbit Kencana Prenada Media Group. 2013.

Kasmir. Pemasaran Bank. Jakarta: Kencana. 2010.

Kasmir. Dasar-dasar Perbankan. Jakarta: PT RajaGrafindo. 2014.

Kertajaya, Hermawan, et al. Syariah Marketing. Bandung: PT. Mizan Pustaka. 2006.

Mangkunegara, A.P. Perilaku Konsumen, Edisi Revisi, Cetakan Keempat. Bandung: PT Refika Aditama. 2009.

Muhamad. Manajemen Bank Syariah. Yogyakarta: UPP STIM YKPN. 2011.

Muhamad. Manajemen Dana Bank Syariah. Jakarta: Rajawali Pers. 2015.

Rivai, Veithzal dan Arviyan Arifin. Islamic Banking: sebuah Teori, knsep, dan Aplikasi. Jakarta: PT Bumi Aksara. 2010.

Sjahdeini, Sutan Remy. Perbankan Syariah Produk-produk dan Aspek-aspek Hukumnya. Edisi Pertama. Jakarta: Kencana. 2014.

Supriono. Manajemen Strategi dan Kebijakan Bisnis. Yogyakarta: BPFE. 1985.

Sutanto, Herry dan Khairul Umam. Manajemen Pemasaran Bank Syariah. Bandung: Pustaka Setia. 2013.

Usmara, Usi. Pemikiran Kreatif Pemasaran. Yogyakarta: Amara Book. 2008.

Winardi, J. Enterpreneur dan Enterpreneurship. Jakarta: Kencana. 2003.

Wirartha, I Made. Metodologi Penetilian Sosial Ekonomi. Yogyakarta: C.V Andi Offset. 2006.

Yuniarti , Vina Sri. Perilaku Konsumen Teori dan Praktik. Bandung Pustaka: Setia. 2015.

Yusanto, Muhammad Ismail dan Muhammad Karebet Widjajakusuma. Menggagas Bisnis Islam. Jakarta: Gema Insani Press. 2002.

Undang-Undang RI Nomor 10 Tahun 1998 tentang Perubahan atas Undangundang Nomor 7 Tahun 1992 tentang Perbankan

Undang-Undang RI Nomor 21 Tahun 2008 tentang Perbankan Syariah

BNI Syariah, Sejarah BNI Syariah, https://www.bnisyariah.co.id/idid/perusahaan/tentangbnisyariah/sejarah,

Boom, Bitner yang dikutip oleh Buchari Alma. 2002, Bauran Pemasaran, Diakses 
http://repository.usu.ac.id/bitstream/123456789/17054/3/Chapter \%20II.pdf,

https://endah240395.wordpress.com/2015/01/05/makalah-umkm/,

https://www.bnisyariah.co.id/id-id/personal/pembiayaan/mikro,

Masse, Rahman Ambo. "Implementasi Prinsip Syariah dalam Akad Pembiayaan Perbankan Syariah (Studi pada Bank Muamalat dan Unit Usaha Syariah Bank BPD Sulselbar di Kota Makassar).", Disertasi Doktor (Makassar: Universitas Islam Negeri Alauddin Makassar, 2015, (online) dalam http://repositori.uin-alauddin.ac.id/623

Oktavianus, Yudhi. "Strategi Pemasaran Produk Kredit Perbankan (Kasus Bank Nagari Cabang Pekanbaru)", diakses dari https://jom.unri.ac.id/index.php/JOMFSIP/article/view/2189,

Zubair, Muhammad Kamal. "Akselerasi Pertumbuhan Bank Syariah Di Indonesia", Jurnal Fakultas Hukum UII, 2008, (online), h. 1. Dalam https://www.neliti.com/publications/89402/akselerasipertumbuhan-bank-syariah-di-indonesia 